\title{
Scope for growth of cultivated Pacific and Gulf of California populations of lion's paw scallop Nodipecten subnodosus, and their reciprocal transplants
}

\author{
Deborah N.S. Purce ${ }^{1}$, Deborah A. Donovan ${ }^{1}$, Alfonso N. Maeda-Martínez ${ }^{2}$ \& Volker Koch $^{3}$ \\ ${ }^{1}$ Biology Department, Western Washington University, St. Bellingham, USA \\ ${ }^{2}$ Unidad Nayarit, Centro de Investigaciones Biológicas del Noroeste S.C., Tepic, Nayarit, México \\ ${ }^{3}$ Universidad Autónoma de Baja California Sur, La Paz, BCS, México \\ Corresponding author: Alfonso N. Maeda Martínez (amaeda04@ cibnor.mx)
}

\begin{abstract}
In the present work, the relative effects of the season (early $v s$. late summer), site (Gulf $v s$. Pacific study sites), the population of origin (Gulf $v s$. Pacific) and associated abiotic variables were determined in two geographically-separated Nodipecten subnodosus populations and their reciprocal transplants, through the scope for growth (SFG) and net growth efficiency (K2) using a portable open-flow system. Results indicate that both energy acquisition and expenditure were significantly affected by season, site, and population factors. Scallop energy acquisition and growth efficiency were highest during the earlier, cooler part of the summer and higher at the Pacific site where food availability was highest. Significantly higher respiration rates were measured for the Pacific scallop population, leading to significantly lower net growth efficiency than scallops of Gulf origin, which indicates a physiological advantage for Gulf scallops during the suboptimal growth conditions present during summer months on both coasts of the Baja California peninsula. It may have important implications for aquaculture enterprises in this region, and may also confirm the genetic divergence between these two geographically separated populations. The advantages of the open-flow system for in situ ecophysiological studies in aquatic organisms are discussed.
\end{abstract}

Keywords: Nodipecten subnodosus; growth; scope for growth; net growth efficiency; energy budget; open-flow system; Baja California

\section{INTRODUCTION}

The Pacific lion's paw scallop (Nodipecten subnodosus Sowerby, 1835) is one of several bivalve species found in the Pacific and Gulf waters of the Baja California Peninsula in northwest Mexico (Barrios-Ruiz et al., 2003). It has been the subject of comprehensive and multidisciplinary studies (Maeda-Martínez \& Lodeiros-Seijo, 2011). It is the largest scallop species in tropical America with a maximum height of $170 \mathrm{~mm}$ and an adductor muscle weight of up to $150 \mathrm{~g}$ (Peña, 2001; Koch et al., 2005). Interest in N. subnodosus as a candidate for aquaculture has sparked the recent investigation into optimal culture conditions and techniques on both sides of the Baja California Peninsula (Barrios-Ruiz et al., 2003; Quintero-Ojeda, 2003; Racotta et al., 2003; Maldonado-Amparo et al., 2004; Villalejo-Fuerte et al., 2004; Koch et al., 2005; Osuna-García, 2006; Taylor et al., 2006; Osuna-García et al., 2008; Freites-Valbuena et al., 2011; Angel-Dapa et al., 2015). Despite the high value of the scallop meats of this species, profitable aquaculture has not been developed yet, and the fishery in Ojo de Liebre Lagoon in Baja California Peninsula has collapsed presumably because of failure in larval recruitment as a result of changes in environmental conditions, without a clear explanation (Maguiño-Napurí et al., 2011). Therefore, there is the need for more information on the physiology and other fields of the species.

High food availability in Baja California's Pacific coast bays indicates the culture conditions necessary for sustaining high $N$. subnodosus productivity. However, during summer months while the California current keeps outer Pacific coast waters relatively cool, shallow Pacific bays can reach $30-32^{\circ} \mathrm{C}$ (Sicard et al., 2006), thus rivaling temperatures of Gulf coast waters. Previous studies found that $N$. subnodosus of Pacific origin suffer higher than average mortality and decreased

Corresponding editor: Cesar Lodeiros 
growth rate when the ambient temperature reaches levels higher than outer Pacific coast averages. Taylor et al. (2006) observed this relationship during summer months in studies conducted at Bahía Magdalena, a shallow coastal lagoon on the Pacific coast of Baja California, and Barrios-Ruiz et al. (2003) observed a similar relationship in studies conducted on scallops of Pacific origin transplanted to warmer Gulf of California sites. The peninsula forms a geographical barrier for the gene flow between the two scallop stocks, and as a result, a clear genetic separation exists (Petersen et al., 2010). Koch et al. (2015) made a study focused on comparing the growth and mortality of lion's paw scallops from the Gulf of California and Pacific populations and their reciprocal transplants, cultured in suspended Nestier trays and bottom structures in Baja California Sur, Mexico. They found that Gulf scallops resisted high diurnal temperature changes at the Pacific site (San Buto) significantly better than Pacific scallops. They also survived generally better than the Pacific population, independent of site, indicating physiological adaptations to high temperatures and low food availability in their habitat. Consequently, they concluded that the Gulf population appears to be more viable for aquaculture operations in coastal lagoons with stressful conditions.

Scope for growth (SFG) is the surplus of energy available for growth beyond that required for maintenance. It represents the amount of energy available to organisms for growth and reproduction after excretion, and metabolic requirements have been met (Warren \& Davis, 1967). Moreover, can be a good indicator of whether biological maintenance under stressful conditions is depleting mollusk energy reserves (Bayne et al., 1979; Buxton et al., 1981; Sicard et al., 1999; LeyvaValencia et al., 2001; Rueda \& Smaal, 2004; Widdows $\&$ Staff, 2006). SFG has been used as a rapid way to assess carrying capacity of coastal waters that are used for bivalve aquaculture, growth and reproductive potential of a species, stress levels of animals growing under polluted conditions and energy balance of bivalves at different environmental conditions (Sobral \& Widdows, 1997; Rueda \& Smaal, 2004; Sará \& Mazzola, 2004; Widdows \& Staff, 2006; Gibbs, 2007; Sará \& Pusceddu, 2008; Sará et al., 2008). It has been shown that SFG decreases under most kinds of environmental stress, as an organism must put energy into physiological adjustments required to cope with the stress in addition to maintaining normal biological functions (Bayne \& Widdows, 1978; Bayne et al., 1979; Savari et al., 1991; Sobral \& Widdows 1997; Tremblay et al., 1998). Also, SFG allows us to calculate net growth efficiency (K2) as a proportion of absorbed energy and thus quantifies how efficiently an organism can convert food into body tissues. K2 has been shown to decrease in the presence of physiological stressors, and negative values represent the exploitation of energy reserves to maintain basic functions (Widdows, 1978, 1985). With these physiological indicators, the longterm growth performance of a cultured species can be predicted by rapid calculations. Beiras et al. (1994) demonstrated that the SFG calculated from these physiological parameters entirely agreed with oyster (Ostrea edulis) performance in the field. It validates the physiological energetics method as a valuable tool for predicting long-term growth performance under constant environmental conditions.

Methods to estimate SFG in mollusks have been described by Widdows \& Staff (1997). These methods are generally carried out in closed chambers, measuring decrements of $\mathrm{O}_{2}$ and food and increments in excreted products (ammonium) during a particular time, provoking a variable response of the organism during incubation. Beiras et al. (1994) developed a practical open-flow system to estimate SFG in oysters, incubating groups of individuals in a single chamber. However, this system requires improvements since polarographic electrodes were used for respiration rate measurements that consume oxygen and therefore give unprecise readings in long-term (hours) measurements. This system could be improved by using temperaturecompensated micro optodes that give precise and quick readings of $\mathrm{O}_{2}$ concentrations. While many studies have considered growth indices and other responses of marine mollusks to physiological and thermal stress, rarely have such studies been conducted in situ, due, in many cases, to cost, time and safety concerns (Dahlhoff \& Menge, 1996; Dahlhoff et al., 2001, 2002; Helmuth $\&$ Hofman, 2001). The advantages of conducting fieldbased physiological studies are that experimental conditions including temperature, salinity, oxygen levels, and suspended particle concentration can be maintained closer to those experienced by animals under natural conditions than cannot be simulated in the lab (Widdows, 1985). Doering \& Oviatt (1986) found that bivalve filter-feeding models using natural seston were more accurate than those based on artificial algal monocultures, and Bayne et al. (1976) used field methods to document physiological differences between distinct bivalve populations, thus demonstrating the feasibility of such an approach to quantifying physiological rates. Our study utilized a portable openflow system that could be installed on lab boats at various field sites to monitor the physiological components of growth indices in the field.

In the present work, the relative effects of the season (early vs. late summer), site (Gulf vs. Pacific study sites), the population of origin (Gulf $v s$. Pacific) and 
associated abiotic variables were determined in $N$. subnodosus populations and their reciprocal transplants through SFG and $\mathrm{K} 2$, using a portable open-flow system.

\section{MATERIALS AND METHODS}

\section{Environmental variables}

In this study, the water temperature was compared at both field sites year-round, chlorophyll- $a$, the organic content of seston (POM), and particle size was measured at each sampling event. Tidbit ${ }^{\circledR}$ data loggers were used for temperature measurements, which permanently affixed to the buoy lines holding the Nestier trays. The data from these loggers were periodically downloaded, and average monthly water temperatures for 2005 were determined. For chlorophyll- $a$ levels, 0.5 and $1 \mathrm{~L}$ samples of water were taken directly from the water adjacent to the lab boat at Gulf and Pacific sites, respectively, were filtered in the field onto nitrocellulose filters and placed on ice. Chlorophyll- $a$ concentrations were analyzed by acetone extraction and photo spectrometry (Jeffrey \& Humphrey, 1975). Triplicate water samples were filtered in the field with a Nalgene hand pump using pre-weighed, pre-ashed $47 \mathrm{~mm} \mathrm{GF/C} \mathrm{filters,} \mathrm{subse-}$ quently stored on ice, to quantify the energy content of seston (POM). In the laboratory, salts were removed with $3 \%$ ammonium formate. Filters were dried at $65^{\circ} \mathrm{C}$ for $24 \mathrm{~h}$, cooled, and weighed to obtain the dry weight of total particulate matter (TPM). Filters were then ashed in a muffle furnace for $4-6 \mathrm{~h}$ at $450^{\circ} \mathrm{C}$ and reweighed to obtain particulate inorganic matter (PIM). Particulate organic matter (POM) was determined by subtracting PIM from TPM. POM's energy content (J $\left.\mathrm{L}^{-1}\right)$ was determined multiplying POM $\left(\mathrm{mg} \mathrm{L}^{-1}\right)$ by 23.5 $\mathrm{J} \mathrm{mg}^{-1} \mathrm{dw}$ (dry weight) (Widdows et al., 1979). For particle size determinations, three $20 \mathrm{~mL}$ sub-samples of water from both sites were analyzed using a particle counter (Beckman-Coulter Multisizer 3, Fullerton, CA).

\section{Experimental organisms}

Scallops ( $41 \pm 8 \mathrm{~mm}$ shell length; $0.8 \pm 0.28 \mathrm{~g}$ dry tissue weight) were collected from Nestier trays suspended to long line cultures carried out simultaneously at two field sites, one in the Gulf of California off Isla Pardito $\left(24^{\circ} 51^{\prime} \mathrm{N}, 110^{\circ} 34^{\prime} \mathrm{W}\right)$ (from here on the "Gulf" site), 80 $\mathrm{km}$ north of La Paz, and the other in the San Buto mangrove channel in Bahía Magdalena on the Pacific coast $\left(24^{\circ} 46^{\prime} \mathrm{N} ; 112^{\circ} 02^{\prime} \mathrm{W}\right.$ (the "Pacific" site) (Fig. 1). These cultures were initiated in December 2004 with spat produced in the hatchery (Mazón-Suástegui et al., 2011), out of broodstock of Nodipecten subnodosus from wild Gulf and Pacific populations (Koch et al., 2015). The spat was transferred to the Nestier trays at both field sites and cultured following the protocol described by Koch et al. (2015). Thus, a reciprocal transplant occurred where juveniles from both populations grew for six months at both field sites.

\section{Experimental design}

After six months, the scope for growth (SFG) of both populations and their reciprocal transplants was determined in situ, once in early summer (Gulf: June 29-July 1; Pacific: July 10-12) and once in late summer (Gulf: August 25-27; Pacific: August 29-31) on a floating lab boat anchored 200-300 m offshore adjacent to the longlines form which the Nestier trays were suspended. These sampling periods were chosen to encompass the rapid increase in temperature that typically occurs during the summer at these sites (Sicard et al., 2006). SFG experiments were conducted in the open-flow system of Figure 2. This system allows for precise determinations of oxygen uptake (respiration) rate, clearance (feeding) rate and food absorption efficiency in the field, to subsequently calculate the SFG. A 12 V DC bilge pump deployed from the lab boat supplied a constant flow of seawater into a tripodmounted holding tank, which maintained constant gravity-pressurized water flow into the open-flow system (Fig. 2). A flotation buoy kept the pump at a constant depth of $0.5 \mathrm{~m}$, and a chamber surrounding the pump with mesh (1-2 mm size) across the open end prevented debris from clogging the pump and macrozooplankton from entering the open-flow system. Water was pumped in at the bottom of the holding tank and flowed out passively from the top through a chamber supply hose.

An overflow hose was connected $10 \mathrm{~cm}$ above the chamber supply hose to pour the excess water into a 60 $\mathrm{L}$ water bath where the chambers were submerged to keep the temperature stable during the physiological determinations. Two additional Tidbit loggers were deployed in the water bath and in one of the control chambers to register temperature during the experiments. Four experimental glass chambers of $1.5 \mathrm{~L}$ bale jars with airtight hinged lids and a leak-proof gasket were submerged up to the neck in the water bath. An additional set of four chambers was used to determine the physiological parameters of both populations simultaneously. Therefore, three chambers held a group of three scallops from the Gulf, and three from the Pacific populations. Two empty chambers served as controls, one for each population. The glass lids of the glass chambers were replaced with Nylamid $^{\odot}$ lids to which a lateral hole of $3.2 \mathrm{~mm}$ was drilled to insert an inlet tube, long enough to reach the bottom of the cham- 


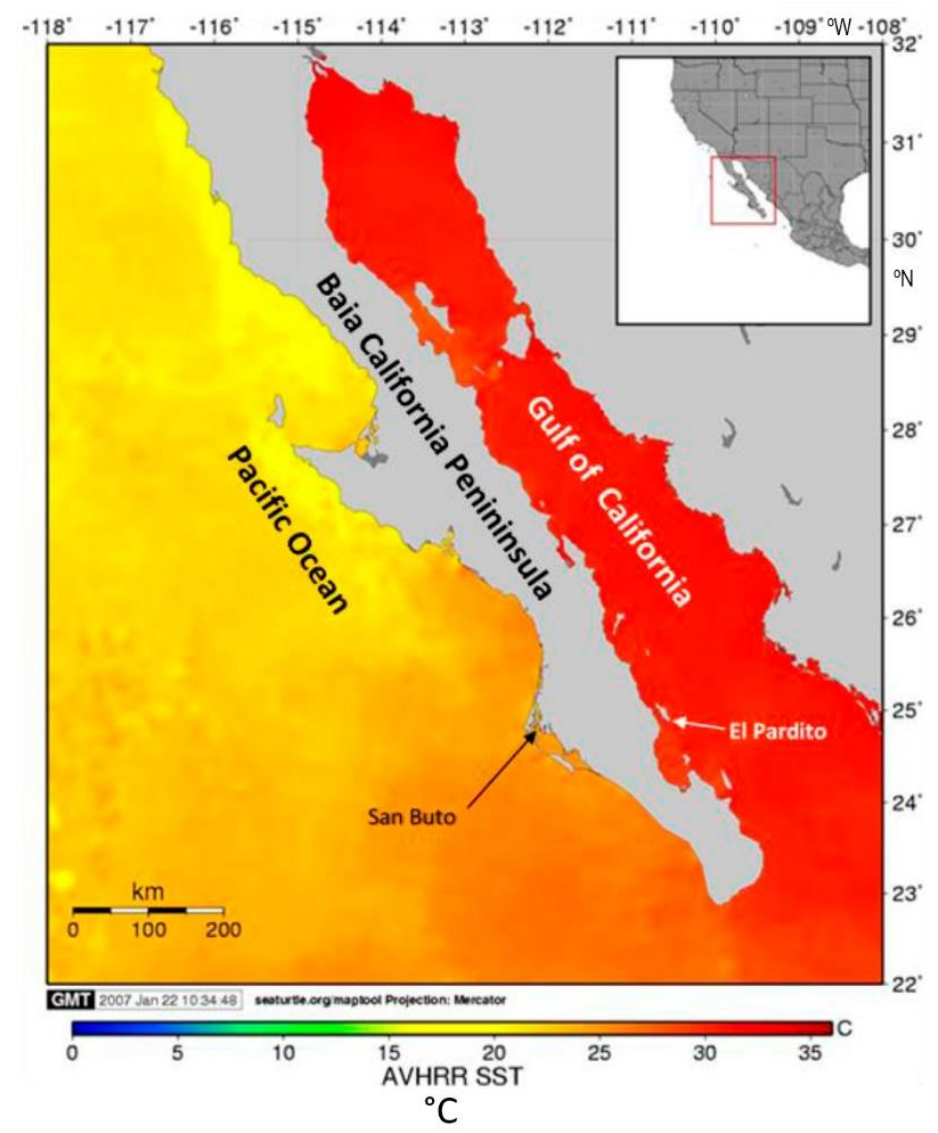

Figure 1. Study sites and the average sea surface temperature (SST; ${ }^{\circ} \mathrm{C}$ ) during August 2005. Maptool SeaTurtle.org.

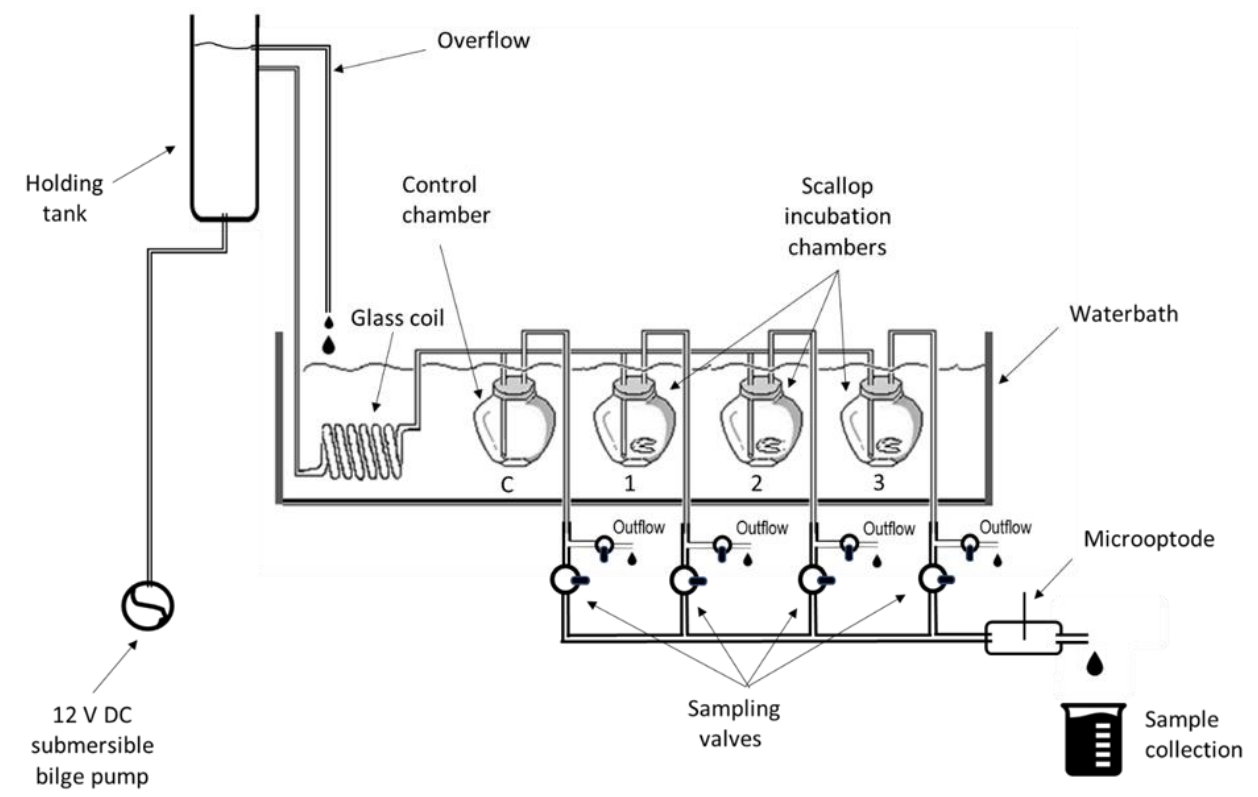

Figure 2. Diagram of the open-flow chamber system installed on the lab boat, for physiological determinations for each lion's paw scallop (Nodipecten subnodosus) population.

ber to allow effective mixing of the water inside the chambers. A central hole of the same diameter was drilled to insert an outlet tubing just to reach the inner surface of the lid. The lids' inner side was conical to allow automatic expulsion of air bubbles that may be trapped inside the chambers. The seawater with natural 
seston was siphoned from the holding tank through a water supply hose made of a plastic tube of $10 \mathrm{~mm}$ diameter. The tube was connected to a glass coil submerged in the water bath to equalize the inflow water temperature to that in the chambers. The coil was connected to the inlet tubes of the chambers.

The outlet tubes were connected to a plastic " $\mathrm{T}$ " connecting in one arm to a control valve for flow regulation through the chambers. Once the valves of each chamber were adjusted to $70 \mathrm{~mL} \min ^{-1}$, they remained untouched during the whole experiment. The scallop clearance rate is independent of the flow rate (López-Sánchez, 2003). In the other "T" arm an aquarium 4-channel manifold with four inlets controlled with plastic valves and only one outlet was connected via Luer-Lock adapter to a flow-through cell housed oxygen micro optode sensor FTCH-PSt1 (PreSens Precision Sensing $\mathrm{GmbH}$ ) with a measurement range of $0-50 \%$ oxygen, and a detection limit of $0.05 \%$ oxygen, to do the oxygen readings and the microalgae samplings. The oxygen Micro Optode sensor with a tip size of $140 \mu \mathrm{m}$ was optimized for a fast response time of $5 \mathrm{~s}$. The sensor was connected to a Microx TX oxygen meter connected to a PC via a USB interface, which included software with which the transmitter can be controlled and data collected.

\section{Physiological measurements}

Physiological responses of $N$. subnodosus were integrated using the energy balance equation and performance was assessed in terms of scope for growth (SFG):

$$
\mathrm{SFG}=(\mathrm{I} \times \mathrm{AE})-\mathrm{R}
$$

where I: ingested energy, AE: absorption efficiency, and R: respired energy (Beiras et al., 1994).

\section{Respired energy}

Respired energy (R) at different temperatures was determined from respiration (oxygen uptake) rates (RR). The RR was calculated by the differences between concentrations in the control chamber vs. experimental chambers containing the scallops (Fig. 3). Scallops from both populations were left undisturbed, before starting, with the water flowing in the chambers $(\sim 1 \mathrm{~h})$ until all organisms were pumping with the valves opened. $\mathrm{O}_{2}$ data from the control chamber were first to read, closing all valves but the control chamber. Once the readings were stable (Fig. 3), the valve of the control chamber was closed, and chamber 1 was opened. A quick drop on concentration was observed to a certain level reflecting the $\mathrm{O}_{2}$ concentration of chamber 1 . After approximately $30 \mathrm{~s}$ of readings every $5 \mathrm{~s}$, the control chamber was read back again by closing

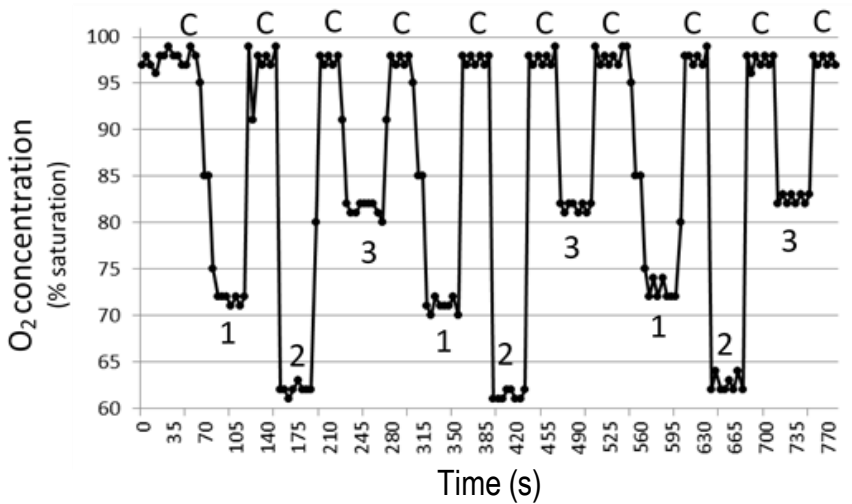

Figure 3. Typical fret-shaped graph of a respiration experiment. Each dot is an $\mathrm{O}_{2}$ measurement taken every 5 seconds with an oxygen Micro Optode with a $140 \mu \mathrm{m}$ sensor. C: control chamber. The numbers are chamber number.

the chamber 1 valve and opening the control chamber's valve. This procedure was repeated with chambers 2 and 3. Three replicates of each reading were obtained by doing the whole procedure three times. In this way, a fret-shaped graph was built of each experiment for later analyses (Fig. 3). The precise flow of the water was determined at the end of each sampling with a 10 $\mathrm{mL}$ graduated cylinder $\left(\mathrm{mL} \mathrm{min}^{-1}\right)$, taken at the outflow port (Fig. 2). The whole experiment at a single temperature lasted $1 \mathrm{~h}$ approximately. This procedure was done four times in a single day at eight-hour intervals beginning at 08:00, 16:00, 24:00 and 08:00 h, and on two occasions: once in early summer and once in late summer.

Respiration rate (RR) was calculated with the formula:

$$
\mathrm{RR}=\left[\left(\mathrm{PO}_{2} \mathrm{c}-\mathrm{PO}_{2} \mathrm{i}\right) \times \mathrm{Q}\right] \times \mathrm{Dw}^{-1}\left(\mathrm{mg} \mathrm{O}_{2} \mathrm{~g}^{-1} \mathrm{~h}^{-1}\right)
$$

where $\mathrm{PO}_{2} \mathrm{C}$ and $\mathrm{PO}_{2} \mathrm{i}$ were the oxygen concentrations in control and scallop chambers respectively, $\mathrm{Q}$ was the flow $\left(\mathrm{mL} \mathrm{h}^{-1}\right)$ through the experimental chambers, and Dw dry tissue weight (mg) of incubated scallops. RR was converted to energy values using the conversion factor of $20.33 \mathrm{~J} \mathrm{mg}^{-1}$ to obtain respired energy (R) J $\mathrm{mg}^{-1} \mathrm{~h}^{-1}$ (Widdows \& Johnson, 1988).

\section{Ingested energy}

Ingested energy $\left(\mathrm{J} \mathrm{g}^{-1} \mathrm{~h}^{-1}\right)$ for each group of three scallops was determined by multiplying clearance rate $\left(\mathrm{CR}, \mathrm{L} \mathrm{h}^{-1}\right)$ by the energy of POM $\left(\mathrm{J} \mathrm{L}^{-1}\right)$ and dividing by the total combined tissue dry weight $(\mathrm{g})$ of the three scallops. The clearance rate is when a given volume of water is completely cleared of seston particles due to filtration activity. In situ clearance rate of scallops was calculated using.

$$
\mathrm{CR}\left(\mathrm{L} \mathrm{h}^{-1}\right)=\text { Flow } \times\left(\mathrm{C}_{1}-\mathrm{C}_{2}\right) / \mathrm{C}_{1}
$$


where $\mathrm{CR}$ is the clearance rate, flow is the flow rate $\left(\mathrm{L} \mathrm{h}^{-1}\right)$, and $\mathrm{C}_{1}$ and $\mathrm{C}_{2}$ are the particle concentrations in the outflows of the control and each scallop chamber (Halldórsson et al., 2005).

For seston POM, the triplicate $20 \mathrm{~mL}$ water samples collected directly from the outflow tubes of each scallop and control chamber were immediately preserved in Lugol's solution. Particle concentration in each sample was determined using a particle counter (Beckman-Coulter Multisizer 3, Fullerton, CA). Energy seston POM ( $\left.\mathrm{J} \mathrm{g}^{-1}\right)$ filtered by the scallops was determined as described previously for monthly determinations.

\section{Absorption efficiency}

Absorption efficiency was determined following the method by Conover (1966). The inorganic and organic content of feces collected from each of the scallop chambers was first gravimetrically determined, as indicated by Strickland \& Parsons (1972). Feces were collected by triplicate and were transferred to ashes preweighed Whatman GF/C filters under vacuum pressure. Filters were rinsed with isotonic 3\% ammonium formate, dried at $60^{\circ} \mathrm{C}$ for $24 \mathrm{~h}$, weighted to obtain the dry weight of feces, and burned in a muffle furnace at $450^{\circ} \mathrm{C}$ for $5 \mathrm{~h}$ to determine the ash-free dry weight of feces. The same procedure was followed for seston from the $20 \mathrm{~mL}$ water samples collected from the control chamber. Absorption efficiency (\%) was calculated with the equation:

$$
\mathrm{AE}=([\mathrm{F}-\mathrm{E}] /[(1-\mathrm{E}) \times \mathrm{F}]
$$

where, $\mathrm{F}$ and $\mathrm{E}$ were the organic content in the food $(\mathrm{F})$ and feces (E).

\section{Absorbed energy \\ Absorbed energy was calculated multiplying ingested energy (I) by absorption efficiency (AE) $\left(\mathrm{J} \mathrm{mg}^{-1} \mathrm{~h}^{-1}\right)$.}

\section{Net growth efficiency}

Net growth efficiency (K2) for the scallop groups was determined by dividing SFG by absorbed energy.

\section{Body condition index}

At the end of each sampling event, the nine experimental scallops from each population were transported alive back to the lab where they were placed into individual plastic bags, flash-frozen in liquid nitrogen, and stored at $-80^{\circ} \mathrm{C}$ until they could be processed. The height, length, and width of both scallop valves were measured; wet weight was recorded for whole tissues and adductor muscles alone. Tissues and adductor muscles were dried to constant weight at $65^{\circ} \mathrm{C}$. Whole tissue dry weight was determined for each scallop, and the combined weight of each set of three scallops was used to normalize physiological rates for each chamber. A body condition index (\%) was estimated for all study animals by dividing adductor muscle dry weight (g) by total tissue dry weight $(\mathrm{g}) \times 100$.

\section{Statistics}

Repeated measures ANOVAs, used to test for diurnal effects over each field session, were not significant for any of the measured physiological rates. For each chamber group, daily averages were calculated for all physiological rates, to be used in the analysis of variance. A three-way, fixed-factor ANOVA was used to test the simple and interactive effects of the season (early vs. late summer), site (Gulf vs. Pacific), and scallop population (Gulf vs. Pacific) on the different physiological rates and growth indices. Because all measurements were taken from scallops grouped into chambers by sets of three, the chambers themselves were considered the experimental unit for analysis purposes. All general linear model assumptions (independence, additivity, equal variance, and normality of data) were met unless otherwise noted. Respiration rates were $\log _{10}$ transformed before analysis, but all other data sets were homoscedastic, so no other transformations were necessary. Statistical significance was accepted at $P<0.05$.

\section{RESULTS}

\section{Environmental variables}

At the Gulf site, monthly temperature means displayed the predicted temperature spike during the summer of 2005. The mean monthly temperature rose $6.4^{\circ} \mathrm{C}$, from $22.1^{\circ} \mathrm{C}$ in June to $28.6^{\circ} \mathrm{C}$ in August (Fig. 4). Gulf site means temperature during the sampling events rose $5.6^{\circ} \mathrm{C}$, from $24.1^{\circ} \mathrm{C}$ during the early summer sampling to $29.7^{\circ} \mathrm{C}$ during the late summer sampling. At the Pacific site, monthly means also displayed the expected spike during the summer months. Here, the mean temperature rose $4.7^{\circ} \mathrm{C}$, from $22.0^{\circ} \mathrm{C}$ in June to $26.7^{\circ} \mathrm{C}$ in August. Pacific site mean temperature during our events rose $3.1^{\circ} \mathrm{C}$, from $26.2^{\circ} \mathrm{C}$ during the early summer sampling to $29.3^{\circ} \mathrm{C}$ during the late summer sampling.

Chlorophyll- $a$ (Chl- $a$ ) concentrations were significantly higher at the Pacific site than at the Gulf site $\left(F_{1,8}\right.$ $=8.03, P=0.009$; ANOVA), although the effect of season was not significant. Chl- $a$ concentrations at the Gulf site ranged from $2.2 \pm 1.5 \mu \mathrm{g} \mathrm{L}^{-1}$ (values represent mean \pm standard error unless otherwise noted) in early summer to $3.8 \pm 1.2 \mu \mathrm{g} \mathrm{L}^{-1}$ in late summer. At the Pacific site, Chl- $a$ levels ranged from $12.7 \pm 3.7 \mu \mathrm{g} \mathrm{L}^{-1}$ in early summer to $9.8 \pm 0.8 \mu \mathrm{g} \mathrm{L}^{-1}$ in late summer. 


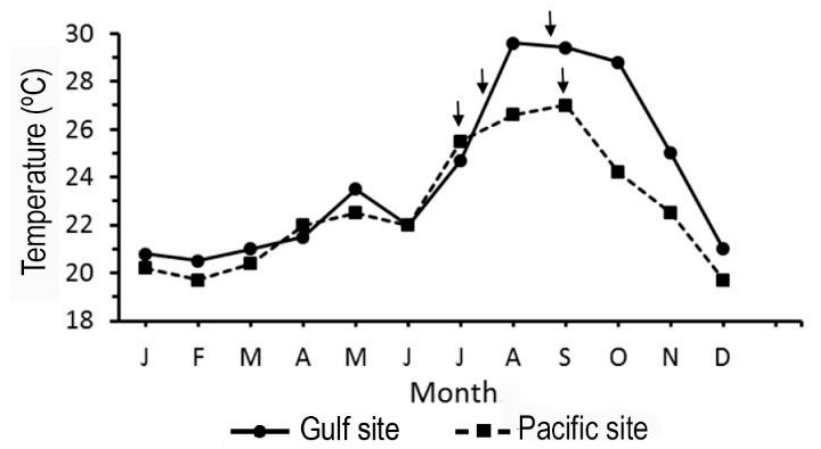

Figure 4. Average monthly water temperature $\left({ }^{\circ} \mathrm{C}\right)$ for 2005 at Gulf and Pacific study sites. Black arrows indicate the times of the four sampling sessions.

Particulate organic matter was measured at each site to determine the amount and energy content of material ingested by the scallops. In the Gulf, mean POM concentration was $2.3 \pm 0.1 \mathrm{mg} \mathrm{L}^{-1}$ in early summer and $2.2 \pm 0.7 \mathrm{mg} \mathrm{L}^{-1}$ in late summer. POM was higher in the Pacific site, with a concentration of $3.9 \pm 0.1 \mathrm{mg} \mathrm{L}^{-1}$ in early summer and $4.5 \pm 1.3 \mathrm{mg} \mathrm{L}^{-1}$ in late summer.

The cell size of particulate matter at the Gulf site had a mean diameter of $16.5 \pm 0.7 \mu \mathrm{m}$ compared to 12.9 $\pm 0.7 \mu \mathrm{m}$ at the Pacific site. Thus, assuming spherical shapes, seston particles in the Gulf had more than twice the mean volume $\left(2350 \pm 300 \mu \mathrm{m}^{3}\right)$ of Pacific seston $\left(1124 \pm 200 \mu \mathrm{m}^{3}\right)$.

\section{Physiological measurements}

Total absorbed energy was significantly affected by season and site (Fig. 5). Overall, absorbed energy was higher in early summer compared to late summer $\left(F_{1,16}\right.$ $=7.96, P=0.012)$ and was higher at the Pacific site than at the Gulf site $\left(F_{1,16}=31.13, P<0.001\right)$. The effect of population on the amount of energy absorbed was not significant $\left(F_{1,16}=0.001, P=0.98\right)$.

Respiration rate was significantly higher for the Pacific scallop population compared to the Gulf scallop population $\left(F_{1,16}=13.76, P=0.002\right.$; Fig. 6). Post-hoc contrasts showed that respiration rates were higher, though not significantly, for Pacific scallops in early summer and were significantly higher in late summer $(P=0.001)$. Respiration decreased from early to late summer for both populations at the Gulf site, whereas respiration increased over the summer in both populations at the Pacific site. This lead to a significant site $\mathrm{x}$ season interaction $\left(F_{1,16}=26.91, P<0.001\right)$.

Scope for growth varied significantly between season $\left(F_{1,16}=13.31, P=0.002\right)$ and site $\left(F_{1,16}=33.54\right.$, $P<0.001$; Fig. 7) treatments. In early summer, SFG was much higher at the Pacific site than at the Gulf site. In late summer, however, SFG in the Pacific was lower

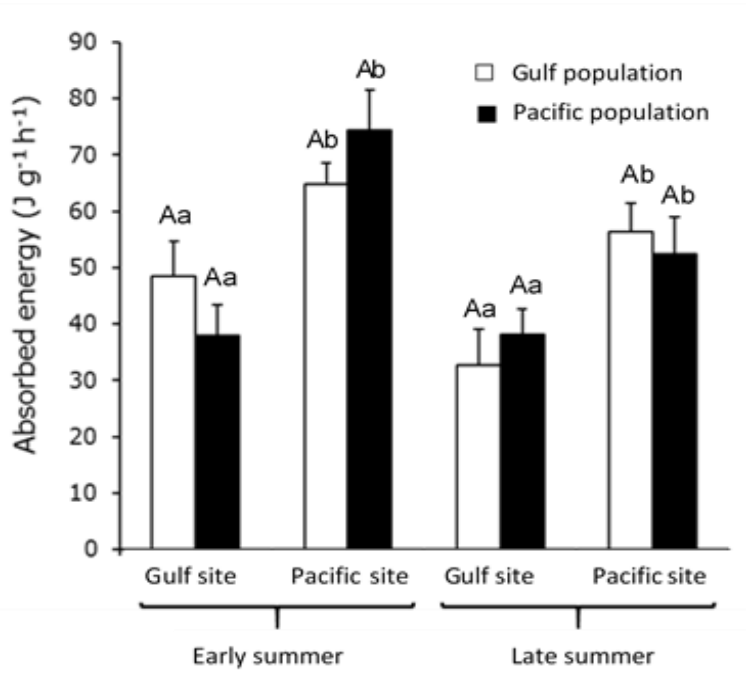

Figure 5. Mean absorbed energy $\left(\mathrm{J} \mathrm{g}^{-1} \mathrm{~h}^{-1}\right)$ for Gulf and Pacific lion's paw scallop (Nodipecten subnodosus) populations during early and late summer sampling periods at Gulf and Pacific study sites. Error bars represent standard error. Different capital letters between populations at the same site and season indicate significant differences at $P$ $<0.05$. Different lowercase letters of the same population at different sites and in the same season indicate significant differences at $P<0.05$.

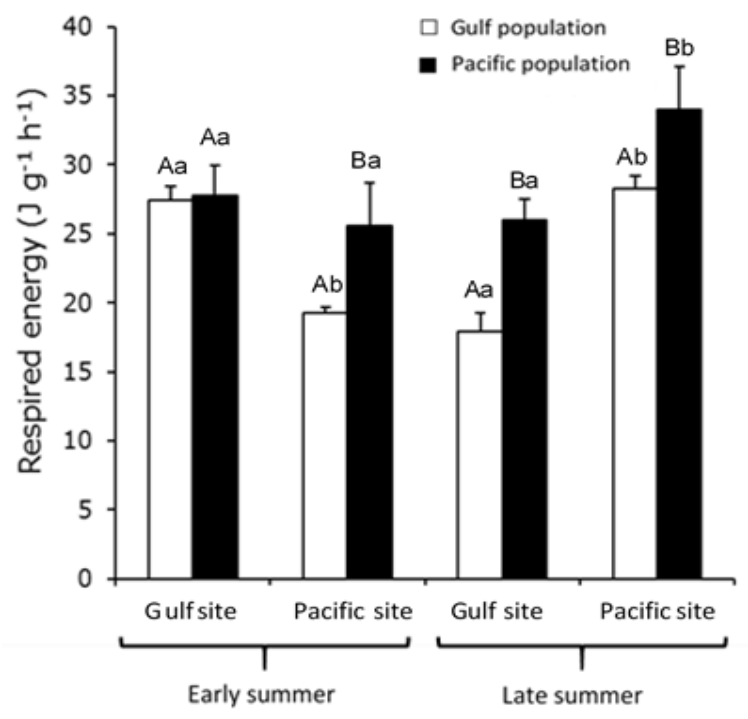

Figure 6. Mean respired energy $\left(\mathrm{J} \mathrm{g}^{-1} \mathrm{~h}^{-1}\right)$ for Gulf and Pacific lion's paw scallop (Nodipecten subnodosus) populations during early and late summer sampling periods and at Gulf and Pacific study sites. Error bars represent standard error. Different capital letters between populations at the same site and season indicate significant differences at $P<0.05$. Different lowercase letters of the same population at different sites and in the same season indicate significant differences at $P<0.05$.

for both populations. Thus, the site's effect was different at the two seasons, resulting in a significant season $\mathrm{x}$ site interaction $\left(F_{1,16}=9.23, P=0.008\right)$. Although 


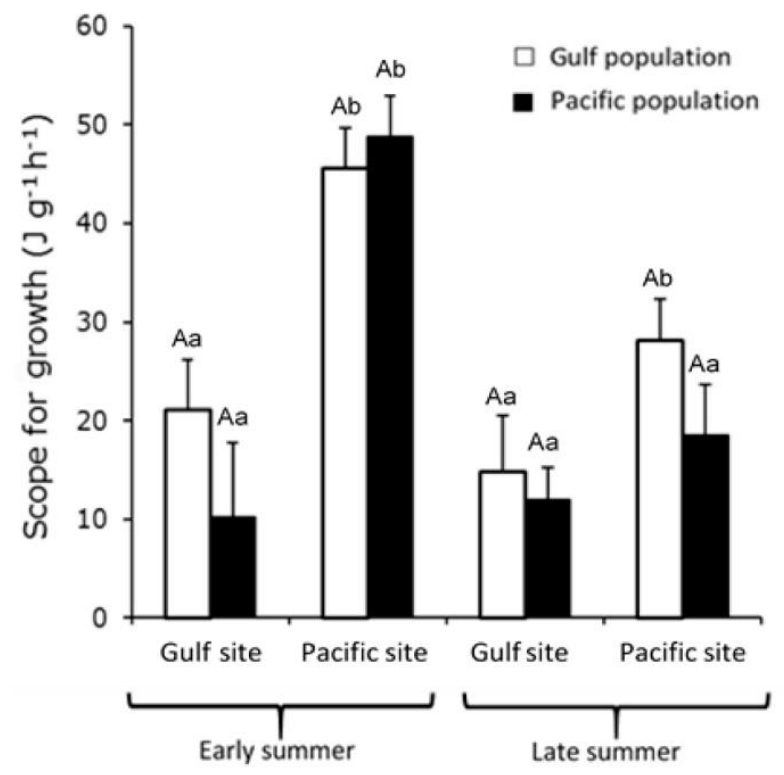

Figure 7. Mean scope for growth $\left(\mathrm{J} \mathrm{g}^{-1} \mathrm{~h}^{-1}\right)$ of Gulf and Pacific lion's paw scallop (Nodipecten subnodosus) populations during early and late summer sampling periods and at Gulf and Pacific study sites. Error bars represent standard error. Different capital letters between populations at the same site and season indicate significant differences at $P<0.05$. Different lowercase letters of the same population at different sites and in the same season indicate significant differences at $P<0.05$.

SFG was lower in the Pacific population scallops during three sampling periods, this difference was not significant $\left(F_{1,16}=1.96, P=0.18\right)$.

Net growth efficiency varied significantly by site $\left(F_{1,16}=13.29, P=0.002\right)$ and there was a significant site $\mathrm{x}$ season interaction $\left(F_{1,16}=6.84, P=0.02\right.$; Fig. 8$)$. As with SFG, K2 was particularly high at the Pacific site in early summer. There was also a significant population effect, with Gulf scallops displaying a higher K2 than Pacific scallops $\left(F_{1,16}=4.82, P=\right.$ 0.043 ).

\section{Body condition index}

Body condition index (BCI) was significantly higher at the Pacific site $\left(F_{1,64}=228.03, P \leq 0.001\right.$; Fig. 9$)$ where adductor muscle mass made up $48.2 \pm 7.9 \%$ of total dry tissue weight (averaged across treatments) compared to only $37.4 \pm 4.8 \%$ in the Gulf. BCI was significantly higher for Gulf scallops compared to Pacific scallops $\left(F_{1,64}=11.43, P=0.001\right)$, but was not significantly different between early and late summer $\left(F_{1,64}=3.06\right.$, $P=0.08)$.

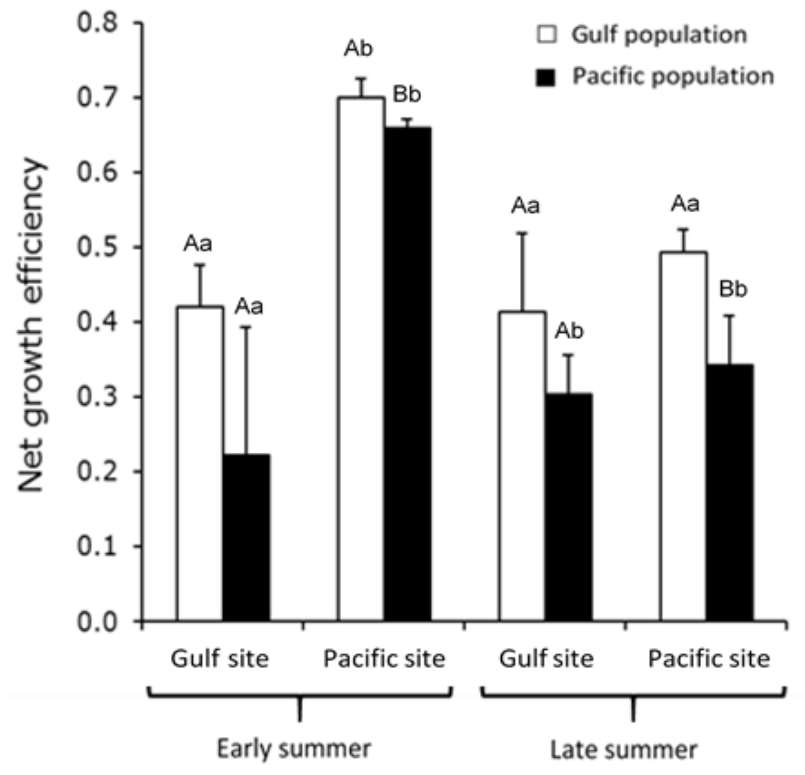

Figure 8. Mean net growth efficiency (K2) of Gulf and Pacific lion's paw scallop (Nodipecten subnodosus) populations during early and late summer sampling periods and at Gulf and Pacific study sites. Error bars represent standard error. Different capital letters between populations at the same site and season indicate significant differences at $P<0.05$. Different lowercase letters of the same population at different sites and in the same season indicate significant differences at $P<0.05$.

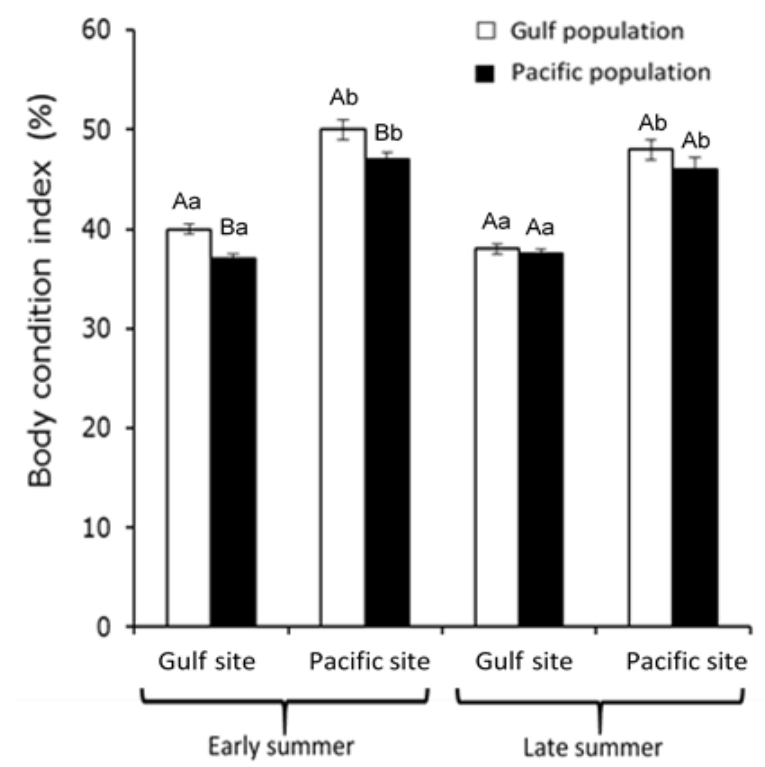

Figure 9. Mean body condition index (\%) of Gulf and Pacific lion's paw scallop (Nodipecten subnodosus) populations during early and late summer sampling periods and at Gulf and Pacific study sites. Error bars represent standard error. Different capital letters between populations at the same site and season indicate significant differences at $P<0.05$. Different lowercase letters of the same population at different sites and in the same season indicate significant differences at $P<0.05$. 


\section{DISCUSSION}

The present work results show that Gulf and Pacific populations and their transplants of Nodipecten subnodosus have significantly different physiological responses. These responses were affected by season of sampling (early vs. late summer), with warm late summer being more stressful for scallops. Site effects were also clearly visible, with the Pacific site offering greater food availability. To some extent, native Gulf scallops were better able to tolerate warm summer conditions, showing lower respiration rates, higher growth efficiency, and higher body condition indices. These results agree with those from Koch et al. (2015) who studied both populations' performance and their reciprocal transplants of $N$. subnodosus, cultured in suspension in the same sites, and season study. Confirms the advantage of using short-term (hours) physiological SFG studies to predict the results of longterm (months) experiments (Beiras et al., 1994).

Environmental conditions related to food acquisition at the Pacific site were more favorable than in the Gulf. The shallow Pacific bay had higher chlorophyll$a$ concentrations, higher cell numbers, and more particulate organic matter than the relatively clear waters of the Gulf. Higher food availability at the Pacific site led to greater energy absorption by the scallops than at the Gulf site, especially during early summer. It is likely that early summer's environmental conditions allowed for more efficient acquisition and incorporation of energy by scallops than during late summer at either site. Lack of significant populationlevel variation in energy acquisition indicates that the energy balance differences observed between Gulf and Pacific scallops must be attributable to differences in energy expenditures.

Overall, Pacific $N$. subnodosus showed significantly higher respiration rates than Gulf scallops. However, increasing temperature over the summer affected the scallops differently at the two sites. Specifically, Gulf scallops at the Gulf site decreased respiration rates over the summer, while Gulf scallops at the Pacific site increased respiration rates. Pacific population respiration, though consistently higher, was less variable across site and season treatments. We did not observe a consistent change in respiration from early to late summer for all scallops as expected based on temperature differences.

In another species of scallops, an inverse relationship between temperature and the metabolic rate has been reported. González et al. (2002) reported that for Argopecten purpuratus, metabolism was higher at $10^{\circ} \mathrm{C}$ than at $18^{\circ} \mathrm{C}$ indicating energy conservation at higher temperatures. In contrast, Aldridge et al. (1995) found that for the mussel Dreissena polymorpha, a $12^{\circ} \mathrm{C}$ increase in temperature resulted in a $265 \%$ increase in metabolic expenditures. It has been shown that for many bivalves, as temperature increases, metabolic rates increase to a maximum or optimal point, after which they tend to decrease sharply (Saucedo et al., 2004).

Higher respiration in Pacific scallops may manifest genetic differences between the two populations (Petersen et al., 2010). With relatively lower temperatures and high food availability along the Pacific coast, it is possible that Pacific scallops typically maintain a higher resting metabolism as part of being adapted to a relatively hospitable environment where energy conservation is not strongly selected. Gulf scallops adapted to warmer waters, and lower food availability may be genetically predisposed to minimize metabolic expenditures even when reared in relatively "comfortable" Pacific coast waters.

Net growth efficiency was significantly higher for scallops of Gulf origin compared to native Pacific scallops. For many mollusks, it has been shown that growth indices decrease or become negative with increased temperature (Widdows, 1978), and the extent to which this occurs may be related to the conditions to which organisms are most often exposed. In this case, Gulf scallops generally experience relatively stressful environmental conditions in terms of temperature and food availability compared to Pacific scallops. These differences in selective pressures may confer a relative physiological advantage to Gulf scallops during seasons of environmental stress, such as exist during summer months around the Baja California Peninsula.

SFG was significantly higher in early summer compared to late summer, but this trend was mainly restricted to the Pacific site. The effect of temperature on bivalve SFG is well studied and shown to vary between species and geographical regions (Widdows, 1978; Bayne et al., 1979; Beiras et al., 1995; Sobral \& Widdows, 1997; Tremblay et al., 1998; Taylor et al., 2006). When studying the interactive effects of food availability and temperature on energy budgets, Bayne $\&$ Newell (1983) and Navarro (2000) found that for the clam Mya arenaria, and the scallop Argopecten purpuratus, respectively, SFG was primarily affected by diet and secondarily by changes in temperature. Our results suggest that temperature has a primary effect on $N$. subnodosus SFG since the significant effect of season on SFG was driven mainly by a large decrease in SFG values measured at the Pacific between early and late summer. SFG values were much higher during the early Pacific sampling period than during any other sampling periods, and in the late summer Pacific site, SFG values decreased despite continued high food abundance. 
We recorded substantial increases in water temperature between our early and late summer sampling periods at both study sites. Although the range of $N$. subnodosus includes the entire Baja California Peninsula, their densities are much lower in warmer southern bay systems. There is some speculation that this may be due to historic over-fishing (Félix-Pico, com. pers.), but it could also be related to the occurrence of conditions outside the temperature acclimation range for $N$. subnodosus, especially in summer. Crisp \& Ritz (1967) suggest that many mollusks acclimate well to temperature changes and maintain high levels of energy balance over a broad range of temperatures. However, Navarro (2001) found that while scallops can acclimate to temperature changes within a specific range, mechanisms for thermal compensation break down outside this range, resulting in low or negative SFG. In the current study, significantly lower SFG during late summer indicates that the highest summer water temperatures at our sites may be outside the range of potential acclimation for $N$. subnodosus. However, it is not clear why this depression was not observed in the late SFG summer, where absolute temperatures were not as high and where food availability was higher, primarily in the Pacific location. Possibly the stress caused by large diurnal temperature variations could have caused the elevated metabolic energy expenditure observed at the Pacific site in late summer leading to the decrease in growth indices. At the Pacific site, diurnal fluctuations were frequently $3^{\circ} \mathrm{C}$ or more and sometimes reached up to $5.5^{\circ} \mathrm{C}$, while at the Gulf site fluctuations rarely exceeded $2^{\circ} \mathrm{C}$ during the study period (Rengstorf, 2007). In another study which measured growth and mortality of scallops from the same transplants as the animals used here, the scallops of Pacific origin descendants from the Guerrero Negro stock, a site where temperature fluctuations are generally small (Sicard et al., 2006), displayed highly depressed growth during periods of high diurnal temperature fluctuations at the Pacific site in San Buto (Rengstorf, 2007).

Both SFG and K2 remained positive throughout the summer, indicating that juvenile scallops from both populations maintained growth year-round and did not rely on stored energy for essential metabolic functions; it was corroborated by changes in the scallop adductor muscle body condition index (BCI) which reflects changes in the organic components associated with tissue growth. BCI is dependent on the balance between food availability, feeding rates, and rates of metabolism. Therefore, BCI can be affected by season, water column height, thermal stress, pollution, or life history stage (Widdows, 1985). Mobilization of tissue biochemical reserves may also occur from, or be exacerbated by, low food availability, which may explain the significantly lower BCI measurements for both $N$. subnodosus populations at the Gulf site where primary productivity is lower, as shown by lower POM and chlorophyll- $a$ concentrations. Lower rates of metabolism in Gulf scallops may also allow for the maintenance of higher energy reserves in the adductor muscle, explaining the significantly higher BCI observed for Gulf scallops during this study. It is unlikely that the population-level differences in BCI were due to differences in adductor muscle exercise since both populations were held in Nestier trays where swimming activity and predator escape responses would have been minimal.

Other studies have examined the effects of different environmental regimes experienced by geographically distinct bivalve populations, including scallops, with similar results. Bricelj et al. (1987) compared individuals from two populations of the Bay scallop, Argopecten irradians irradians that were translocated from distinct latitudes along the western Atlantic. Here, the northern population of $A$. irradians irradians failed to efficiently adjust metabolic rates to increases in temperature during summer months at the southern transplant site. For the Catarina scallop, Argopecten ventricosus, also native to Baja's Gulf and Pacific waters, Peña (2001) showed that Gulf population scallops were adapted to grow and survive in the stressful Gulf environment. Pacific A. ventricosus were not adapted to these conditions, and this was attributed to underlying genetic differences between the populations. Thompson \& Newell (1985) found that for latitudinally isolated Mytilus edulis populations, mussels from the colder latitude exhibited a larger decrease in SFG, as temperature increased, while Bayne and Widdows (1978) showed that even for adjacent $M$. edulis populations, localized, seasonal environmental variation could have significant effects on relative ecological fitness.

Though not considered in this study, other studies of bivalves have found that growth and body condition indices vary with age class (Bricelj et al., 1987; Savari et al., 1991). In interspecies comparisons, it was shown that smaller scallops almost always have a positive scope for growth while larger scallops may have low or negative SFG during certain months (reviewed by Thompson \& MacDonald, 2006). Widdows (1978) similarly found that smaller individuals are less stressed at higher temperatures than larger animals for mussels. Therefore, it may be important to consider how physiological rates of Gulf and Pacific N. subnodosus might vary in larger, older scallops. The treatment of specific energy budgets determined for juvenile scallops in this study may not apply to older, sexually 
mature animals, with potentially important implications for aquaculture.

Finally, in this work, we determined SFG with a portable open-flow system that allows precise determinations of respiration and ingestion rates in the field. Our system produces a continuous flow of water inside the chambers, while $\mathrm{O}_{2}$ readings and water samples for seston evaluation are taken without interruption. Thus, oxygen and seston depletion and ammonia buildup during incubation are eliminated. Besides, it ensures proper mixing of water, automatic expulsion of air bubbles, and avoids water stratification and seston sedimentation inside the chambers. The use of temperature-compensated Micro Optodes for the $\mathrm{O}_{2}$ measurements allowed building a fret-shaped graph while running the experiment, ensuring consistency of the readings and detecting any problem with performance (pumping cessation) of any individual from the group of bivalves incubated. Indeed, our results are consistent despite the time elapsed from the first to the last reading $(8-10 \mathrm{~min})$ of a particular chamber (Fig. 3), with confidence limits (SDEV) lower than $10 \%$ of the mean in respired energy measurements (Fig. 6).

\section{CONCLUSIONS}

Our study suggests that geographic and seasonal variation in temperature and other abiotic variables should be taken into consideration when seeking to maximize the profitability of using Nodipecten subnodosus aquaculture along the coast of the Baja California Peninsula. We found that both Gulf and Pacific populations of N. subnodosus are better able to acquire and absorb energy in early $v s$. late summer and the Pacific vs. the Gulf. In the coastal waters of the Gulf of California and shallow Pacific coast bays like Magdalena Bay, the marked increase in late summer water temperature results in physiological stress in $N$. subnodosus. This stress is mitigated to some extent by high food availability at the Pacific site.

The significant metabolic differences between Gulf and Pacific populations are likely due to Gulf scallops' superior energy conservation abilities, adapted to the relatively stressful conditions (higher temperatures, less food) in the Gulf. Scope for growth and net growth efficiency of both populations suffer in the warmest part of summer, but, as suggested by the maintenance of energy budget components, juvenile Gulf scallops are probably at an advantage at both Pacific and Gulf side due to lower rates of metabolic energy loss.

Whether it is advisable to preferentially use $N$. subnodosus spat from Gulf population scallops in Pacific bays was not determined within this study's scope. We recommend that any use or management of $N$. subnodosus as a marine resource also considers aspects of genetic diversity and structure of the natural populations.

\section{ACKNOWLEDGMENTS}

We are grateful for the contributions of D.E. Schneider and A. Acevedo-Gutiérrez as DNSP's thesis committee members. The Centro de Investigaciones Biológicas del Noroeste (CIBNOR) and the Universidad Autónoma de Baja California Sur (UABCS) in La Paz contributed significant resources to this project. We are thankful for the technical and field support of María Teresa Sicard, Armando Monge, Francisco Hernández, Salvador Costa, Iban Murillo, Francisco Sinsel, Yadira Trejo Hernández, Julio Solís, Agnese Mancini, José Hernández, Ismael, Güero, Beto, and Don Pepe. Erin Kenney created technical drawings. The Western Washington University Biology Department partially supported this work, a generous scholarship from SeaSpace, a WWU Ross Travel Grant, and a NSF GK12 graduate fellowship (DGE - 0338354).

\section{REFERENCES}

Aldridge, D.W., Payne, B.S. \& Miller, A.C. 1995. Oxygen consumption, nitrogenous excretion, and filtration rates of Dreissena polymorpha at acclimation temperatures between 20 and $32^{\circ} \mathrm{C}$. Canadian Journal of Fisheries and Aquatic Sciences, 52: 1761-1767.

Angel-Dapa, M.A., Arellano-Martínez, M., CeballosVázquez, B.P. Acosta-Salmón, H. \& Saucedo, P. 2015. Comparative analysis of the reproductive strategy of lion's paw scallop Nodipecten subnodosus in Baja California Sur, Mexico. Latin American Journal of Aquatic Research, 43(3): 616-620.

Barrios-Ruiz, D., Chávez-Villalba, J. \& CáceresMartínez, C. 2003. Growth of Nodipecten subnodosus (Bivalvia: Pectinidae) in $\mathrm{La} \mathrm{Paz}$ Bay, Mexico. Aquaculture Research, 34: 633-639.

Bayne, B.L. \& Newell, R.C., 1983. Physiological energetics of marine mollusks. In: Saleuddin, A.S.M. \& Wilbur, K.M. (Eds.). The Mollusca. Academic Press, New York, pp. 407-515.

Bayne, B.L. \& Widdows, J. 1978. The physiological ecology of two populations of Mytilus edulis L. Oecologia, 37: 137-162.

Bayne, B.L., Widdows, J. \& Newell, R.I.E. 1976. Physiological measurements on estuarine bivalve molluses in the field. In: Keegan, B.F., Ceidigh, P.O. $\&$ Boaden, P.J.S. (Eds.). Biology of benthic organisms. Pergamon Press, Oxford, pp. 57-68. 
Bayne, B.L., Moore, M.N., Widdows, J., Livingstone, D.R. \& Salkeld, P. 1979. Measurement of the responses of individuals to environmental stress and pollution: studies with bivalve molluscs. Philosophical Transactions of the Royal Society B: Biological Sciences, 286: 563-581.

Beiras, R., Pérez-Camacho, A. \& Albentosa, M. 1994. Comparison of the scope for growth with the growth performance of Ostrea edulis seed reared at different food concentrations in an open-flow system. Marine Biology, 119: 227-233.

Beiras, R., Pérez-Camacho, A. \& Albentosa, M. 1995. Short-term and long-term alteration in the energy budget of young oyster Ostrea edulis L. in response to temperature change. Journal of Experimental Marine Biology and Ecology, 186: 221-236.

Bricelj, V.M., Epp, J. \& Malouf, R.E. 1987. Comparative physiology of young and old cohorts of the bay scallop Argopecten irradians irradians (Lamarck): mortality, growth, and oxygen consumption. Journal of Experimental Marine Biology and Ecology, 112: 7391.

Buxton, C.D., Newell, R.C. \& Field, J.G. 1981. Responsesurface analysis of the combined effects of exposure and acclimation temperatures on filtration, oxygen consumption, and scope for growth in the oyster Ostrea edulis. Marine Ecology, 6: 73-82.

Conover, R.J. 1966. Assimilation of organic matter by zooplankton. Limnology and Oceanography, 11: 338345.

Crisp, D.J. \& Ritz, D.A. 1967. Temperature acclimation in barnacles. Journal of Experimental Marine Biology and Ecology, 1: 236-256.

Dahlhoff, E.P. \& Menge, B.A. 1996. Influence of phytoplankton concentration and wave exposure on the ecophysiology of Mytilus californianus. Marine Ecology Progress Series, 144: 97-107.

Dahlhoff, E.P., Buckley, B.A. \& Menge, B.A. 2001. Physiology of the rocky intertidal predator Nucella ostrina along an environmental stress gradient. Ecology, 82: 2816-2829.

Dahlhoff, E.P., Stillman, J.H. \& Menge, B.A. 2002. Physiological community ecology: variation in metabolic activity of ecologically important rocky intertidal invertebrates along environmental gradients. Integrative and Comparative Biology, 42: 862-871.

Doering, P.H. \& Oviatt, C.A. 1986. Application of filtration rate modes to field populations of bivalves: an assessment using experimental mesocosms. Marine Ecology Progress Series, 31: 265-275.

Freites-Valbuena, L., Mazón-Suástegui, J.M., MaedaMartínez, A.N., Koch, V., Osuna-García, M., RuizVerdugo, C., et al. 2011. Nursery, intermediate culture and grow-out of the scallops Nodipecten nodosus and
N. subnodosus. In: Maeda-Martínez, A.N. \& Lodeiros, C. Eds. Biología y cultivo de los moluscos pectínidos del género Nodipecten. Editorial Limusa, Ciudad de México, pp. 313-350.

Gibbs, M.T. 2007. Sustainability performance indicators for suspended bivalve aquaculture activities. Ecological Indicators, 7: 94-107.

González, M.L., López, D.A., Perez, M.C. \& Castro, J.M. 2002. Effect of temperature on the scope for growth in juvenile scallops Argopecten purpuratus (Lamark, 1819). Aquaculture International, 10: 339-349.

Halldórsson, H.P., Svavarsson, J. \& Granmo, A. 2005. The effect of pollution on scope for growth of the mussel (Mytilus edulis L.) in Iceland. Marine Environmental Research, 59: 47-64.

Helmuth, B.S. \& Hofman, G.E. 2001. Microhabitats, thermal heterogeneity, and patterns of physiological stress in the rocky intertidal zone. Biological Bulletin, 201: 374-384.

Jeffrey, S.W. \& Humphrey, G.F. 1975. New spectrophotometric equation for determining chlorophylls a, b, c1 and $\mathrm{c} 2$ in higher plants, algae and natural phytoplankton. Biochemie und Physiologie der Pflanzen, 167: 191-194.

Koch, V., Mazón-Suástegui, J.M., Sinsel, F., RoblesMungaray, M. \& Dunn, D. 2005. Lion's paw scallop (Nodipecten subnodosus, Sowerby 1835) aquaculture in Bahía Magdalena, Mexico: effects of population density and season on juvenile growth and morality. Aquaculture Research, 36: 505-512.

Koch, V., Rengstorf, A., Taylor, M., Mazón-Suástegui, J.M., Sinsel, F. \& Wolff, M. 2015. Comparative growth and mortality of cultured Lion's Paw scallops (Nodipecten subnodosus) from Gulf of California and Pacific populations and their reciprocal transplants. Aquaculture Research, 46: 185 -201.

Leyva-Valencia, I., Maeda-Martínez, A.N., Sicard, M.T., Roldan, L. \& Robles-Mungaray, M. 2001. Halotolerance, upper thermotolerance, and optimum temperature for growth of the penshell Atrina maura (Sowerby, 1835). Journal of Shellfish Research, 20: 49-54.

López-Sánchez, J.A. 2003. Tasa de filtración y aclaramiento en la almeja mano de león (Nodipecten subnodosus Sowerby, 1835) a dos tallas, en función de la temperatura y cantidad de alimento. Tesis de Magíster, Centro de Investigaciones Biológicas del Noroeste, La Paz, 85 pp.

Maeda-Martínez, A.N. \& Lodeiros-Seijo, C. 2011. Biología y cultivo de los moluscos pectínidos del género Nodipecten. Editorial Limusa, Ciudad de México.

Maguiño-Napurí, R., Maeda-Martínez, A.N., MoctezumaCano, T., Valle-Meza, G. \& Acosta-Salmón, H. 2011. 
Larval abundance and spat collection of the lion's paw scallop Nodipecten subnodosus in Ojo de Liebre Lagoon, Baja California Sur, Mexico. Ciencias Marinas, 37(1): 51-57.

Maldonado-Amparo, R., Ramírez J.L., Ávila, S. \& Ibarra, A.M. 2004. Triploid lion-paw scallop (Nodipecten subnodosus Sowerby); growth, gametogenesis, and gametic cell frequencies when grown at a high food availability site. Aquaculture, 235: 185-205.

Mazón-Suástegui, J.M., Maeda-Martínez, A.N., RoblesMungaray, M., De La Roche, J.P., Rupp, G.S., Mendes-De-Bem, M., Velasco, L.A. \& FreitesValbuena, L.F. 2011. Advances on the seed production of Nodipecten spp. In: Maeda-Martínez, A.N. \& Lodeiros, C. (Eds.). Biología y cultivo de los moluscos pectínidos del género Nodipecten. Editorial Limusa, Ciudad de México, pp. 275-311.

Navarro, J.M. 2000. Interactive effects of diet and temperature on the scope for growth of the scallop Argopecten purpuratus during reproductive conditioning. Journal of Experimental Marine Biology and Ecology, 247: 67-83.

Navarro, J.M. 2001. Fisiología energética de pectínidos iberoamericanos. In: Maeda-Martínez, A.N. (Ed.). Los moluscos pectínidos de Iberoamérica: ciencia y acuicultura. McGraw-Hill, Ciudad de México, pp. 6173.

Osuna-García, M. 2006. Efecto de la densidad en el cultivo de la almeja mano de león Nodipecten subnodosus. Tesis de Magíster, Instituto Politécnico Nacional, Centro Interdisciplinario de Ciencias Marinas, Ciudad de México, 82 pp.

Osuna-García, M., Hernández-Llamas, A. \& MazónSuástegui, J.M. 2008. Production dynamics of the giant lions-paw scallop Nodipecten subnodosus cultivated offbottom. Aquaculture, 274: 260-267.

Peña, J.B. 2001. Taxonomía, morfología, distribución y hábitat de los pectínidos iberoamericanos. In: MaedaMartínez, A.N. (Ed.). Los moluscos pectínidos de Iberoamérica: ciencia y acuicultura. McGraw-Hill, Ciudad de México, pp. 1-23.

Petersen, J.L., Ibarra-Obando, A.M. \& May, B. 2010. Nuclear and mtDNA lineage diversity in wild and cultured Pacific lion-paw scallop, Nodipecten subnodosus (Baja California Peninsula, Mexico). Marine Biology, 157: 2751-2767.

Quintero-Ojeda, N.V. 2003. Crecimiento y supervivencia de la almeja mano de león Nodipecten subnodosus (Sowerby II, 1835), en dos artes de cultivo, en el estero El Cardón, Laguna San Ignacio, B.C.S., México. Tesis de Licenciatura, Universidad Autónoma de Baja California Sur, La Paz, 63 pp.

Racotta, I.S., Ramírez, J.L., Ibarra, A.M., RodríguezJaramillo, M.C., Carreño, D. \& Palacios, E. 2003. Growth and gametogenesis in the lion-paw scallop
Nodipecten (Lyropecten) subnodosus. Aquaculture, 217: 335-349.

Rengstorf, A. 2007. Comparative growth and mortality of cultured lion's paw scallops (Nodipecten subnodosus) from Gulf and Pacific populations and their reciprocal transplants in BCS, Mexico. M.Sc. Thesis, ISATEC, University of Bremen, Bremen, 58 pp.

Rueda, J.L. \& Smaal, A.C. 2004. Variation of the physiological energetic of the bivalve Spisula subtruncata (da Costa, 1778) within an annual cycle. Journal of Experimental Marine Biology and Ecology, 301: 141 $-157$.

Sará, G. \& Mazzola, A. 2004. The carrying capacity for Mediterranean bivalve suspension feeders: evidence from analysis of food availability and hydrodynamics and their integration into a local model. Ecological Modelling, 179: 281-296.

Sará, G. \& Pusceddu, A. 2008. Scope for growth of Mytilus galloprovincialis (Lmk, 1819) in oligotrophic coastal waters (Southern Tyrrhenian Sea, Italy). Marine Biology, 156: 117-126.

Sará, G., Romano, C., Widdows, J. \& Staff, F.J. 2008. Effect of salinity and temperature on feeding physiology and scope for growth of an invasive species (Brachidontes pharaonic, Mollusca: Bivalvia) within the Mediterranean Sea. Journal of Experimental Marine Biology and Ecology, 363: 130-136.

Saucedo, P.E., Ocampo, L., Monteforte, M. \& Bervera, H. 2004. Effect of temperature on oxygen consumption and ammonia excretion in the Calafia mother-of-pearl oyster, Pinctada mazatlanica (Hanley, 1856). Aquaculture, 229: 377-387.

Savari, A., Lockwood, A.P.M. \& Sheader, M. 1991. Variations in the physiological state of the common cockle (Cerastoderma edule (L.)) in the laboratory and in Southampton water. Journal of Molluscan Studies, 57: 33-44.

Sicard, M.T., Maeda-Martínez, A.N., Ormart, P., Reynoso-Granados, T. \& Carvalho, L. 1999. Optimum temperature for growth in the Catarina scallop (Argopecten ventricosus-circularis, Sowerby II, 1842). Journal of Shellfish Research, 18: 385-392.

Sicard, M.T., Maeda-Martínez, A.N., Lluch-Cota, S.E., Lodeiros, C., Roldan-Carrillo, L.M. \& MendozaAlfaro, R. 2006. Frequent monitoring of temperature: an essential requirement for site selection in bivalve aquaculture in tropical-temperate transition zones. Aquaculture Research, 37: 1040-1049.

Sobral, P. \& Widdows, J. 1997. Effects of elevated temperatures on the scope for growth and resistance to air exposure of the clam Ruditapes decussatus (L.), from southern Portugal. Scientia Marina, 61: 163-171. 
Strickland, J.D. \& Parsons, T.R. 1972. A practical handbook of seawater analysis. Fisheries Research Board, Vancouver, pp. 87-89.

Taylor, M.H., Koch, V., Wolff, M. \& Sinsel, F. 2006. Evaluation of different shallow water culture methods for the scallop Nodipecten subnodosus using biologic and economic modeling. Aquaculture, 254: 301-316.

Thompson, R.J. \& MacDonald, B.A. 2006. Physiological integrations and energy partitioning. In: Shumway, S.E. \& Parsons, G.J. (Eds.). Scallops: biology, ecology and aquaculture. Elsevier, Amsterdam, pp. 493-520.

Thompson, R.J. \& Newell, R.I.E. 1985. Physiological response to temperature in two latitudinally separated populations of the mussel, Mytilus edulis. $19^{\text {th }}$ European Marine Biology Symposium, Devon, pp. 481-495.

Tremblay, R., Myrand, B., Sevigny, J., Blier, P. \& Guderley, H. 1998. Bioenergetic and genetic parameters in relation to susceptibility of blue mussels, Mytilus edulis (L.) to summer mortality. Journal of Experimental Marine Biology and Ecology, 221: 2758.

Villalejo-Fuerte, M., Arellano-Martínez, M., RoblesMungaray, M. \& Ceballos-Vázquez, B.P. 2004. Notes on the growth, survival, and reproduction of the lion's paw scallop Nodipecten subnodosus maintained in a suspended culture. Hidrobiológica, 14: 161-165.
Warren, L.E. \& Davis, G.W. 1967. Laboratory studies on the feeding, bioenergetics and growth of fish. In: Gerking, S.D. (Ed.). The biological basis of freshwater fish production. Blackwell Scientific Publications, Oxford, pp. 175-214.

Widdows, J. 1978. Physiological indices of stress in Mytilus edulis. Journal of the Marine Biological Association of the United Kingdom, 58: 125-142.

Widdows, J. 1985. Physiological measurements. In: Bayne, B.L., Brown, D.A., Burns, K., Dixon, D.R., Ivanovici, A., Livingstone, D.R., et al. (Eds.). The effects of stress and pollution on marine animals. Praeger, New York, pp. 3-39.

Widdows, J. \& Johnson, D. 1988. Physiological energetics of Mytilus edulis: scope for growth. Marine Ecology Progress Series, 46: 113-121.

Widdows, J. \& Staff, F. 1997. Practical procedures for the measurement of scope for growth. Plymouth Marine Laboratory, Plymouth.

Widdows, J. \& Staff, F. 2006. Biological effects of contaminants: measurement of scope for growth in mussels. ICES Technical Marine Environmental Sciences, 40: 1-30.

Widdows, J., Fieth, P. \& Worrall, C. 1979. Relationships between seston, available food and feeding activity in the common mussel Mytilus edulis. Marine Biology, 50: $195-207$. 